\title{
High Expression of MRE11-RAD50-NBS1 Is Associated with Poor Prognosis and Chemoresistance in Gastric Cancer
}

\author{
BOLAG ALTAN ${ }^{1,2^{*}}$, TAKEHIKO YOKOBORI ${ }^{1,3^{*}}$, MUNENORI IDE $^{4}$, TUYA BAI $^{1}$, TORU YANOMA $^{1}$, \\ AKIHARU KIMURA ${ }^{1}$, NORIMICHI KOGURE ${ }^{1}$, MASAKI SUZUKI ${ }^{1}$, PINJIE BAO $^{1}$, \\ ERITO MOCHIKI $^{5}$, KYOICHI OGATA ${ }^{1}$, TADASHI HANDA ${ }^{4}$, KYOICHI KAIRA ${ }^{2}$, \\ MASAHIKO NISHIYAMA ${ }^{3}$, TAKAYUKI ASAO ${ }^{6}$, TETSUNARI OYAMA $^{4}$ and HIROYUKI KUWANO ${ }^{1}$ \\ Departments of ${ }^{1}$ General Surgical Science, ${ }^{2}$ Oncology Clinical Development, \\ ${ }^{3}$ Molecular Pharmacology and Oncology, and ${ }^{4}$ Diagnostic Pathology, \\ Gunma University Graduate School of Medicine, Gunma, Japan; \\ ${ }^{5}$ Department of Digestive Tract and General Surgery, Saitama Medical Center, \\ Saitama Medical University, Saitama, Japan; \\ ${ }^{6}$ Big Data Center for Intergrative Analysis, \\ Gunma University Initiative for Advance Research, Maebashi, Gunma, Japan
}

\begin{abstract}
Background: The MRN complex of meiotic recombination 11 (MRE11), DNA repair protein Rad50 (RAD50) and Nijmegen breakage syndrome 1 (NBS1) proteins coordinate the detection and repair of DNA doublestrand breaks (DSBs). DNA DSB repair-dependent chemoresistance likely has an effect on the treatment of human cancer. Materials and Methods: We investigated the expression of MRN complex in human gastric cancer $(G C)$ tissues using immunohistochemistry and analyzed its clinical significance and prognostic relevance. Results: The expression of MRN complex was significantly associated with clinical factors including poorer prognosis and negatively associated with the expression of DNA damage marker phosphorylated $H 2 A$ histone family, member $X$ $(\gamma H 2 A X)$ in the nucleus. In the biopsy specimens, low expression of MRE11 correlated with good response to chemotherapy and surgical resection after down-staging by chemotherapy. Furthermore, the expression levels of MRE11
\end{abstract}

*These Authors contributed equally to this study.

Correspondence to: Bolag Altan, Ph.D., Department of Oncology Clinical Development, Gunma University, Graduate School of Medicine, Gunma, Japan. Tel: +81 272208222, Fax: +81 272208230, e-mail: altanbolag@gunma-u.ac.jp and Takehiko Yokobori, MD, Ph.D., Department of Molecular Pharmacology and Oncology, Gunma University, Graduate School of Medicine, Gunma, Japan. Tel: +81 272208224, Fax: +81 272208230, e-mail: bori45@gunma-u.ac.jp

Key Words: Double-strand break repair, DSB, MRN complex, cisplatin, paclitaxel. and RAD50 were independent predictors of surgical resection after chemotherapy. Conclusion: The high expression of MRN complex constituents could be a predictor for poor prognosis and chemoresistance in $G C$.

Gastric cancer (GC) is the fifth most common cancer worldwide, with nearly one million diagnoses annually (1). Treatment with aggressive and adjuvant chemotherapy in advanced GC has led to improved survival rates, but the prognosis for patients with refractory GC with unresectable regions remains poor and unsatisfactory (2). Therefore, further research is required to identify new therapeutic targets capable of overcoming chemoresistance in order to improve the prognosis in these patients.

DNA damage is known to be associated with chemoresistance, cancer progression, genomic instability, and carcinogenesis (3-5). DNA double-strand breaks (DSBs) are one of the most severe threats to cancer cell survival, and are repaired by the mechanisms of homologous recombination and non-homologous end-joining. Moreover, DNA DSB repair genes are often activated in several refractory types of cancer, including GC, and are reported to convey chemo- and radiotherapy resistance $(6,7)$. As such, targeting DSB repair genes presents as a promising strategy for eliminating chemoresistant cancer cells.

DSB repair is initiated through the combined efforts of ataxia telangiectasia mutated (ATM) and a protein complex consisting of meiotic recombination 11 (MRE11), RAD50 double strand break repair protein (RAD50) and Nijmegen breakage syndrome 1 (NBS1) proteins to form the MRE11RAD50-NBS1 (MRN) complex $(8,9)$. In the nucleus, the MRN complex binds to sites of DNA DSBs where it recruits 
and activates ATM, which can then phosphorylate multiple substrates including phosphorylated H2A histone family, member $\mathrm{X}(\gamma \mathrm{H} 2 \mathrm{AX})$; p53 binding protein (153BP1); structural maintenance of chromosomes protein 1 (SMC1); breast cancer, early-onset 1 (BRCA1); and checkpoint kinase 2 (CHK2) to trigger cell-cycle arrest and apoptosis of cancer cells (10-15). Notably, the MRN complex is associated with increased chemoresistance in several cancer types via its role in DNA DSB repair (16-19). Matsutani et al. reported that the expression levels of MRE11, RAD50, and NBS1 were higher in GC tissues when compared to corresponding noncancerous tissues (20). However, the role of the MRN complex in cancer progression, prognosis, and chemosensitivity has not yet been investigated in clinical GC samples.

The purpose of this study was to clarify the clinical significance of MRN complex in biopsy specimens from 210 patients undergoing radical resection and 78 with unresectable tumors obtained at initial diagnosis from chemotherapy-naïve patients with GC. Specimens were subjected to immunohistochemistry to assess MRE11, RAD50 and NBS1 expression in order to evaluate their effect on clinicopathological factors, prognosis, and clinical response after chemotherapy.

\section{Materials and Methods}

Patients and clinical samples. Four serial surgical specimens for tissue microarrayevaluation of MRE11, RAD50, NBS1 and $\gamma \mathrm{H} 2 \mathrm{AX}$ expression were obtained from each of 210 patients with GC who underwent radical resection. Patient characteristics are described in Table I.

Three serial biopsy specimens were obtained from each of 78 patients with GC (10 stage III, 68 stage IV) who presented with unresectable GC at initial diagnosis. Twenty-one out of 78 cases were treated with surgery after down-staging by chemotherapy. The remaining 57 cases remained inoperable after down-staging by chemotherapy. Forty-seven out of the 78 patients received S-1 (tegafur-gimeracil-oteracil potassium) orally on days 1-14 plus paclitaxel as an intravenous infusion on days 1,8 , and 15 of a 4week cycle. The remaining 31 patients received S-1 orally on days 1-21 plus cisplatin as an intravenous infusion on day 8 of a 5-week cycle(21). Other characteristics are described in Table II.

All clinical GC samples were obtained at Gunma University Hospital, Department of General Surgical Science, from January 1999 and March 2006, and were used in accordance with institutional guidelines and the Helsinki Declaration after obtaining written informed consent from all participants. The clinicopathological factors were obtained from pathological reports and medical records including age, gender, tumor location, histology, Lauren's classification, tumor depth, lymph node metastasis, lymphatic invasion, venous invasion, clinical stage, firstline chemotherapy regimen, and clinical response by first-line chemotherapy. The pathological features of the specimens were classified based on the 14th edition of the Japanese Classification of Gastric Carcinoma outlined by the Japanese Gastric Cancer Association (22).
Tissue microarrays. Clinical samples were formalin-fixed and paraffin-embedded, and then stored in the archives of the Clinical Department of Pathology, Gunma University Hospital. For each patient, one paraffin block containing representative non-necrotic tumor areas was selected. Two GC tissue cores (2.0-mm diameter per tumor) were punched out from the representative areas near the invasive front and transferred into the paired recipient paraffin block using a tissue array instrument (Beecher Instruments, Silver Spring, MD, USA).

Immunohistochemistry. Immunohistochemical staining was performed with $2-\mu \mathrm{m}$-thick sections. All sections were incubated at $60^{\circ} \mathrm{C}$ for $60 \mathrm{~min}$ and deparaffinized in xylene, rehydrated, and then incubated with fresh $0.3 \%$ hydrogen peroxide in $100 \%$ methanol for $30 \mathrm{~min}$ at room temperature to block endogenous peroxidase activity. After rehydration through a graded series of ethanol solutions, antigen retrieval was carried out in Immunosaver (NJ15T, NEM, Tokyo, Japan) at $98-100^{\circ} \mathrm{C}$ for $30 \mathrm{~min}$, and then sections were passively cooled to room temperature. After rinsing in $0.1 \mathrm{M}$ phosphate-buffered saline (PBS, pH 7.4), sections were incubated in Protein Block Serum-Free Reagent (DAKO, Carpinteria, CA, USA) for $30 \mathrm{~min}$ to block non-specific binding sites. The sections were then incubated with rabbit monoclonal antibody to MRE11 (ab109623; Abcam, Cambridge, MA, USA), mouse monoclonal antibody to RAD50 (ab87918; Abcam), rabbit monoclonal antibody NBS1 (ab175800; Abcam) and mouse monoclonal antibody to $\gamma \mathrm{H} 2 \mathrm{AX}$ (phospho-S139) (ab26350; Abcam) at a dilution of 1:300 in PBS containing $0.1 \%$ bovine serum albumin overnight at $4{ }^{\circ} \mathrm{C}$ and then incubated at room temperature for $30 \mathrm{~min}$. The reaction was visualized using the Histofine Simple Stain MAX-PO (Multi) Kit (Nichirei, Tokyo, Japan) according to the manufacturer's instructions. The chromogen 3,3'-diaminobenzidine tetrahydrochloride was applied as a $0.02 \%$ solution in $50 \mathrm{mM}$ ammonium acetate-citrate acid buffer ( $\mathrm{pH} 6.0$ ) containing $0.005 \%$ hydrogen peroxide. The sections were lightly counterstained with hematoxylin and mounted. Negative controls were incubated without primary antibody, and no detectable staining was evident.

Evaluation of immunostaining. Immunohistochemical slides were scanned and evaluated by two experienced researchers (Cohen's $\mathrm{K}=0.839$ ). The intensity of staining for the nuclear MRN complex and $\gamma \mathrm{H} 2 \mathrm{AX}$ was scored as follows: 0 : no staining; $1+$ : weak staining; $2+$ : moderate staining; $3+$ : strong staining. The percentage of nuclear-stained cells was calculated by examining at least $10^{3}$ cancer cells in five representative areas. The percentage of staining of nuclear MRN complex and $\gamma \mathrm{H} 2 \mathrm{AX}$ was scored as follows: 0: no staining; $1+: 1-25 \% ; 2+: 26-50 \% ; 3+: 51-100 \%$. The final score was defined as the percentage score multiplied by the intensity score $(0$; $1+; 2+; 3+; 4+; 6+; 9+)$. Nuclear immunoreactivity of the MRN complex and $\gamma \mathrm{H} 2 \mathrm{AX}$ was scored on a scale of $0-9+$ with scores of 0-4+, and 5-9+ defined as low and high nuclear expression, respectively(23).

Fluorescent immunohistochemistry. The sections were prepared, and endogenous peroxidase was blocked as described above. The sections were then boiled in citrate buffer ( $\mathrm{pH}$ 6.4) for $15 \mathrm{~min}$ in a microwave, and then incubated with fresh $0.3 \%$ hydrogen peroxide in $100 \%$ methanol for $30 \mathrm{~min}$ at room temperature to block endogenous peroxidase activity. Nonspecific binding sites were blocked by incubation with Protein Block Serum-Free Reagent for 
Table I. Association of meiotic recombination 11 (MRE11), DNA repair protein Rad50 (RAD50) and Nijmegen breakage syndrome 1 (NBS1) complex expression in 210 gastric cancer surgical samples with clinicopathological factors.

\begin{tabular}{|c|c|c|c|c|c|c|c|c|c|}
\hline \multirow[t]{2}{*}{ Factor } & \multicolumn{3}{|c|}{ MRE11 } & \multicolumn{3}{|c|}{ RAD50 } & \multicolumn{3}{|c|}{ NBS1 } \\
\hline & Low $(n=90)$ & High $(n=120)$ & $p$-Value & Low $(n=54)$ & High $(n=156)$ & $p$-Value & Low $(n=94)$ & High $(n=116)$ & $p$-Value \\
\hline Age $($ mean $\pm S D)$, years & $64 \pm 12.15$ & $65 \pm 10.32$ & 0.5694 & $65 \pm 10.89$ & $63 \pm 11.38$ & 0.3056 & $63 \pm 10.66$ & $65 \pm 11.09$ & 0.467 \\
\hline \multicolumn{10}{|l|}{ Gender, $\mathrm{n}(\%)$} \\
\hline Male & $65(72.2)$ & $82(68.3)$ & \multirow[t]{2}{*}{0.5428} & $38(70.4)$ & $109(69.9)$ & \multirow[t]{2}{*}{0.9451} & $72(76.6)$ & $75(64.7)$ & \multirow[t]{2}{*}{0.0604} \\
\hline Female & $25(27.8)$ & $38(31.7)$ & & $16(29.6)$ & $47(30.1)$ & & $22(23.4)$ & $41(35.3)$ & \\
\hline \multicolumn{10}{|l|}{ Histology, n (\%) } \\
\hline Well, moderate & $35(38.9)$ & $44(36.7)$ & \multirow[t]{2}{*}{0.7422} & $18(33.3)$ & $61(39.1)$ & \multirow[t]{2}{*}{0.4507} & $41(43.6)$ & $38(32.8)$ & \multirow[t]{2}{*}{0.1063} \\
\hline Poor, signet & $55(61.1)$ & $76(63.3)$ & & $36(66.7)$ & $95(60.9)$ & & $53(56.4)$ & $78(67.2)$ & \\
\hline \multicolumn{10}{|c|}{ Lauren's classification, n (\%) } \\
\hline Diffuse & $48(53.3)$ & $65(54.2)$ & \multirow[t]{3}{*}{0.5201} & $32(59.3)$ & $81(51.9)$ & \multirow[t]{3}{*}{0.4789} & $42(44.7)$ & $71(61.2)$ & \multirow[t]{3}{*}{$0.0108 *$} \\
\hline Intestinal & $34(37.8)$ & $39(32.5)$ & & $18(33.3)$ & $55(35.3)$ & & $43(45.7)$ & $30(25.9)$ & \\
\hline Mixed & $8(8.9)$ & $16(13.3)$ & & $4(7.4)$ & $20(12.8)$ & & $9(9.6)$ & $15(12.9)$ & \\
\hline \multicolumn{10}{|l|}{ Tumor depth, n (\%) } \\
\hline SM, MP & $30(33.3)$ & $25(20.8)$ & \multirow[t]{2}{*}{$0.0415^{*}$} & $17(31.5)$ & $38(24.4)$ & \multirow[t]{2}{*}{0.3049} & $26(27.7)$ & $29(25.0)$ & \multirow[t]{2}{*}{0.6629} \\
\hline SS, SE, SI & $60(66.7)$ & $95(79.2)$ & & $37(68.5)$ & $118(75.6)$ & & $68(72.3)$ & $87(75.0)$ & \\
\hline \multicolumn{10}{|c|}{ Lymph node metastasis, $\mathrm{n}(\%)$} \\
\hline Absent & $38(42.2)$ & $29(24.2)$ & \multirow[t]{2}{*}{$0.0055^{*}$} & $24(44.4)$ & $43(27.6)$ & \multirow[t]{2}{*}{$0.0218^{*}$} & $35(37.2)$ & $32(27.6)$ & \multirow[t]{2}{*}{0.1358} \\
\hline Present & $52(57.8)$ & $91(75.8)$ & & $30(55.6)$ & $113(72.4)$ & & $59(62.8)$ & $84(72.4)$ & \\
\hline \multicolumn{10}{|l|}{ Lymphatic invasion, $\mathrm{n}(\%)$} \\
\hline Absent & $12(13.3)$ & $7(5.8)$ & 0.0608 & $7(13.0)$ & $12(7.7)$ & 0.2445 & $11(11.7)$ & $8(6.9)$ & 0.2274 \\
\hline Present & $78(86.7)$ & $113(94.2)$ & & $47(87.0)$ & $144(92.3)$ & & $83(88.3)$ & $108(93.1)$ & \\
\hline Venous invasion, $\mathrm{n}(\%)$ & & & & & & & & & \\
\hline Absent & $71(78.9)$ & $81(67.5)$ & 0.0677 & $42(77.8)$ & $110(70.5)$ & 0.3034 & $72(76.6)$ & $80(69.0)$ & 0.2188 \\
\hline Present & $19(21.1)$ & $39(31.5)$ & & $12(22.2)$ & $46(29.5)$ & & $22(23.4)$ & $36(32.0)$ & \\
\hline Clinical stage, n (\%) & & & & & & & & & \\
\hline I & $17(18.9)$ & $16(13.3)$ & $0.0074 *$ & $11(20.4)$ & $22(14.1)$ & 0.0751 & $17(18.1)$ & $16(13.8)$ & 0.1653 \\
\hline II & $39(43.3)$ & $30(25.0)$ & & $23(42.6)$ & $46(29.5)$ & & $35(37.2)$ & $34(29.3)$ & \\
\hline III & $26(28.9)$ & $56(46.7)$ & & $17(31.5)$ & $65(41.7)$ & & $35(37.2)$ & $47(40.5)$ & \\
\hline IV & $8(8.9)$ & $18(15.0)$ & & $3(5.5)$ & $23(14.7)$ & & $7(7.5)$ & $19(16.4)$ & \\
\hline$\gamma \mathrm{H} 2 \mathrm{AX}, \mathrm{n}(\%)$ & & & & & & & & & \\
\hline Low & $56(62.2)$ & $92(76.7)$ & $0.0232 *$ & $19(35.2)$ & $129(82.7)$ & $<0.0001 *$ & $51(54.3)$ & $97(83.6)$ & $<0.0001^{*}$ \\
\hline High & $34(37.8)$ & $28(23.3)$ & & $35(64.8)$ & $27(17.3)$ & & $43(45.7)$ & $19(16.4)$ & \\
\hline RAD50, n (\%) & & & & & & & & & \\
\hline Low & $36(40.0)$ & $18(15.0)$ & $<0.0001^{*}$ & & & & & & \\
\hline High & $54(60.0)$ & $102(85.0)$ & & & & & & & \\
\hline NBS1, n $(\%)$ & & & & & & & & & \\
\hline Low & $54(60.0)$ & $40(33.3)$ & $<0.0001^{*}$ & & & & & & \\
\hline High & $36(40.0)$ & $80(66.7)$ & & & & & & & \\
\hline
\end{tabular}

SM: Submucosal invasion; MP: muscularis propria invasion; SS: subserosal invasion; SE: serosal invasion; SI: surrounding organ invasion, $\gamma \mathrm{H} 2 \mathrm{AX}$ : DNA damage marker phosphorylated H2A histone family, member X. *Significant difference.

$30 \mathrm{~min}$, and the sections were incubated with the above-mentioned primary antibodies against NBS1, RAD50, and MRE11 diluted in PBS containing $0.01 \%$ bovine serum albumin for $3 \mathrm{~h}$ at room temperature. Multiplex covalent labeling with tyramide signal amplification (Opal ${ }^{\mathrm{TM}}$ 3-Plex Kit; PerkinElmer, Waltham, MA USA) was performed according to the manufacturer's protocol. All sections were counterstained with 4',6-diamidino-2-phenylindole (DAPI) and examined under an All-in-One BZ-X710 fluorescence microscope (KEYENCE Corporation).

Statistical analysis. Statistically significant differences were analyzed with the Student's $t$-test and $\chi^{2}$ test for continuous and categorical variables, respectively. Survival curves were generated by Kaplan-Meier analysis and differences were examined by logrank testing. In addition, univariate and multivariate survival analyses were performed using Cox's proportional hazards model for survival and logistic regression model for radical surgery after down-staging. Values of $p<0.05$ and $p<0.1$ were considered as statistically significant and indicative of trending data, respectively. All statistical analyses were performed using JMP 9.0 software (SAS Institute Inc., Cary, NC, USA).

\section{Results}

Nuclear expression of MRN complex and $\gamma H 2 A X$ in clinical $G C$ samples. We used immunohistochemistry to investigate 
Table II. Univariate and multivariate analyses of clinicopathological factors according to the Japanese Classification of Gastric Carcinoma affecting overall survival in 210 patients with gastric cancer and disease-free survival in 186 patients with primary gastric cancer. Protein expression was determined from surgical specimens.

\begin{tabular}{|c|c|c|c|c|c|c|c|c|c|c|c|c|}
\hline \multirow[t]{2}{*}{ Clinicopathological variable } & \multicolumn{3}{|c|}{ Univariate } & \multicolumn{3}{|c|}{ Multivariate (MRE11) } & \multicolumn{3}{|c|}{ Multivariate (RAD50) } & \multicolumn{3}{|c|}{ Multivariate (NBS1) } \\
\hline & $\mathrm{RR}$ & $95 \% \mathrm{CI}$ & $p$-Value & $\mathrm{RR}$ & $95 \% \mathrm{CI}$ & $p$-Value & $\mathrm{RR}$ & $95 \% \mathrm{CI}$ & $p$-Value & $\mathrm{RR}$ & $95 \% \mathrm{CI}$ & $p$-Value \\
\hline \multicolumn{13}{|l|}{ Overall survival } \\
\hline Age: $<65 / \geq 65$ years & 1.17 & $0.78-1.77$ & 0.4467 & - & - & - & - & - & - & - & - & - \\
\hline Gender: Male/female & 1.17 & $0.76-1.86$ & 0.4908 & - & - & - & - & - & - & - & - & - \\
\hline \multicolumn{13}{|l|}{ Histology grade: } \\
\hline Differentiated/undifferentiated & 0.73 & $0.47-1.12$ & 0.1546 & - & - & - & - & - & - & - & - & - \\
\hline Tumor depth: SM, MP/SS, SE, SI & 3.63 & $2.38-5.67$ & $<0.0001 *$ & 1.24 & $0.62-2.65$ & 0.5507 & 1.26 & $0.62-2.69$ & 0.5348 & 1.00 & $0.69-1.46$ & 1.0003 \\
\hline Lymph node metastasis: Absent/present & 2.65 & $1.60-4.63$ & $<0.0001 *$ & 0.73 & $0.34-1.62$ & 0.4372 & 0.72 & $0.33-1.58$ & 0.4074 & 1.12 & $0.73-1.73$ & 0.5868 \\
\hline Lymphatic invasion: Absent/present & 3.75 & $1.41-15.27$ & $0.0051^{*}$ & 1.86 & $0.61-8.09$ & 0.2996 & 1.85 & $0.60-8.03$ & 0.3063 & 1.00 & $0.59-1.76$ & 0.9833 \\
\hline Venous invasion: Absent/present & 2.20 & $1.43-3.34$ & $0.0004^{*}$ & 1.72 & $1.10-2.64$ & $0.0177 *$ & 1.74 & $1.12-2.65$ & $0.0141^{*}$ & 1.29 & $0.93-1.76$ & 0.1195 \\
\hline Stage: I, II/III, IV & 4.11 & $2.60-6.74$ & $<0.0001 *$ & 3.83 & $1.88-8.44$ & $0.0001 *$ & 3.68 & $1.83-7.97$ & $0.0001 *$ & 1.50 & $0.99-2.31$ & 0.0537 \\
\hline MRE11expression: Low/high & 1.56 & $1.03-2.41$ & $0.0367 *$ & 0.99 & $0.64-1.57$ & 0.9661 & - & - & - & - & - & - \\
\hline RAD50 expression: Low/high & 1.81 & $1.10-3.17$ & $0.0185^{*}$ & - & - & - & 1.54 & $0.93-2.71$ & 0.0935 & - & - & - \\
\hline NBS1 expression: Low/high & 1.74 & $1.15-2.70$ & $0.0088^{*}$ & - & - & - & - & - & - & 1.70 & $1.28-2.27$ & $0.0003^{*}$ \\
\hline \multicolumn{13}{|l|}{ Disease-free survival (stage I, II, III) } \\
\hline Age: $<65 / \geq 65$ years & 1.22 & $0.80-1.89$ & 0.3484 & - & - & - & - & - & - & - & - & - \\
\hline Gender: Male/female & 1.18 & $0.49-0.74$ & 0.4968 & - & - & - & - & - & - & - & - & - \\
\hline \multicolumn{13}{|l|}{ Histology grade: } \\
\hline Differentiated/undifferentiated & 1.28 & $0.2-0.82$ & 0.27 & - & - & - & - & - & - & - & - & - \\
\hline Tumor depth: SM, MP/SS, SE, SI & 0.33 & $0.18-0.57$ & $<0.0001 *$ & - & - & - & - & - & - & 2.05 & $1.30-3.28$ & 0.561 \\
\hline Lymph node metastasis: Absent/present & 2.75 & $1.66-4.85$ & $<0.0001 *$ & - & - & - & - & - & - & 1.03 & $0.51-2.11$ & 0.5021 \\
\hline Lymphatic invasion: Absent/present & 5.96 & $1.88-36.21$ & $0.0007 *$ & - & - & - & - & - & - & 2.18 & $0.73-9.36$ & 0.205 \\
\hline Venous invasion: Absent/present & 2.02 & $1.26-3.14$ & $0.0037 *$ & - & - & - & - & - & - & 1.78 & $1.19-2.63$ & 0.344 \\
\hline Stage: I, II/III, IV & 3.01 & $1.95-4.74$ & $<0.0001 *$ & - & - & - & - & - & - & 2.04 & $1.06-4.08$ & 0.0953 \\
\hline MRE11expression: Low/high & 1.39 & $0.81-2.58$ & 0.2397 & - & - & - & - & - & - & - & - & - \\
\hline RAD50 expression: Low/high & 1.25 & $0.81-1.94$ & 0.3264 & - & - & - & - & - & - & - & - & - \\
\hline NBS1 expression: Low/high & 3.00 & $1.29-3.55$ & $0.0023 *$ & - & - & - & - & - & - & 1.45 & $0.99-2.14$ & $0.0008^{*}$ \\
\hline
\end{tabular}

MRE11: Meiotic recombination 11; RAD50: DNA-repair protein Rad50; NBS1: Nijmegen breakage syndrome 1; RR: relative risk; CI: confidence interval; SM: submucosal invasion; MP: muscularis propria invasion; SS: subserosal invasion; SE: serosal invasion; SI: surrounding organ invasion. *Significant result.

the nuclear expression of MRE11, RAD50, NBS1, and $\gamma \mathrm{H} 2 \mathrm{AX}$ in four serial surgical specimens obtained from 210 GC samples. Results were as follows: high $v s$. low expression: MRE11: 120 vs. 90 (57.1\% vs. $42.9 \%)$; RAD50: 156 vs. 54 low (74.3\% vs. 25.7\%); NBS1: 116 vs. 94 low (55.2\% vs. $44.8 \%)$; $\gamma \mathrm{H} 2 \mathrm{AX}: 62$ vs. 148 low $(29.5 \%$ vs. $70.5 \%$ ). Representative results of the immunohistochemistry are shown in Figure 1.

Our analysis revealed enhanced nuclear expression of DNA damage marker $\gamma \mathrm{H} 2 \mathrm{AX}$ in specimens with low expression of MRN complex. Conversely, nuclear $\gamma \mathrm{H} 2 \mathrm{AX}$ expression was decreased in specimens with high expression of the MRN complex (Figure 1A).

Association between MRN complex expression and clinicopathological factors of 210 patients with GC. High nuclear MRE11 expression was significantly positively associated with tumor depth $(p=0.0415)$, lymph node metastasis $(p=0.0055)$, clinical stage $(p=0.0074)$, low nuclear expression of $\gamma \mathrm{H} 2 \mathrm{AX}(p=0.0232)$, and nuclear accumulation of RAD50 $(p<0.0001)$ and NBS1 $(p<0.0001)$. Co-expression of MRN complex was validated in identical GC tissue using multi-fluorescent immunohistochemistry (Figure 2). High nuclear RAD50 expression was significantly positively associated with lymph node metastasis $(p=0.0218)$ and low nuclear expression of $\gamma \mathrm{H} 2 \mathrm{AX}$ $(p<0.0001)$. High nuclear NBS1 expression was significantly associated with diffuse-type GC $(p=0.0108)$ and low nuclear expression of $\gamma \mathrm{H} 2 \mathrm{AX}(p<0.0001)$ (Table I).

Prognostic significance of nuclear MRN complex and $\gamma H 2 A X$ expression in $G C$. The overall survival rates of patients with GC assigned to the high MRN/low $\gamma \mathrm{H} 2 \mathrm{AX}$ group were significantly lower than that of those assigned to the low MRN/high $\gamma \mathrm{H} 2 \mathrm{AX}$ group (survival according to: MRE11, $p=0.0385$; RAD50, $p=0.0242$; NBS1, $p=0.0094$; 
and $\gamma \mathrm{H} 2 \mathrm{AX}, p=0.0003$ ) (Figure 1B). This finding also extended to patients with GC without synchronous unresectable metastases (stage I-III, $n=184$ ), where the disease-free survival rates for patients assigned to the high MRN/low $\gamma \mathrm{H} 2 \mathrm{AX}$ were lower than those of patients assigned to the low MRN/high $\gamma \mathrm{H} 2 \mathrm{AX}$ group (survival according to: MRE11, $p=0.0729$; RAD50, $p=0.0402$; NBS1, $p=0.0032$; and $\gamma \mathrm{H} 2 \mathrm{AX}, p=0.0204$ ) (Figure 1B). Multivariate analysis revealed that high nuclear expression of NBS1 was an independent prognostic factor (relative risk $(\mathrm{RR})=1.70$, $95 \%$ confidence interval $(\mathrm{CI})=1.28-2.27, p=0.0003$ ) (Table II). Moreover, high nuclear expression of NBS1 was also an independent predictor of recurrence after surgical resection $(\mathrm{RR}=1.45, \mathrm{CI}=0.99-2.14, p=0.0008)$ (Table II).

Association of MRN complex expression and clinicopathological features of unresectable GC. We first confirmed that the evaluation of MRN complex expression by immunohistochemistry was also possible using the biopsy samples (Figure 3). Our analyses revealed that high nuclear MRE11 expression $(n=56)$ in 78 biopsy samples was significantly associated with poor clinical response to first-line chemotherapy ( $p=0.0436)$ and high nuclear RAD50 expression $(\mathrm{n}=59)$ may be associated with histological type $(p=0.0856)$, tumor depth $(p=0.0768)$ and clinical response $(p=0.0803)$ (Table III). Moreover, improved surgical resection after downstaging using first-line chemotherapy $(21 / 78,26.9 \%)$ was associated with the low nuclear expression of MRE11, RAD50 and NBS1 $(p<0.0001, p<0.0001, p=0.0501$ respectively $)$ (Table III).

Relationship of MRN complex expression and chemotherapeutic response in unresectable GC. The overall survival rates of patients with GC assigned to the high MRN group were significantly lower than those assigned to the low MRN group (survival according to: MRE11, $p<0.0001$; RAD50, $p=0.0005$; NBS1, $p=0.0186$ ) (Figure 4A), as were those of patients with GC treated with cisplatin $(\mathrm{n}=31)$ (survival according to: MRE11, $p=0.0073$; RAD50, $p=0.0658$; NBS1, $p=0.0314$ ) (Figure 4B) and those patients treated by paclitaxel $(n=47)$ (survival according to: MRE11, $p=0.0042$; RAD50, $p=0.0027$; NBS1, $p=0.0962$ ) (Figure 4C).

Multivariate analysis revealed that high expression of nuclear MRN complex in unresectable GC biopsy samples was an independent prognostic factor (MRE11: $R R=4.18$, 95\% $\mathrm{CI}=2.03-9.80, \quad p<0.0001 ; \quad \mathrm{RAD} 50: \quad \mathrm{RR}=3.73$, $95 \% \mathrm{CI}=1.22-8.17, \quad p<0.0001 ; \quad \mathrm{NBS} 1, \quad \mathrm{RR}=2.78,95 \%$ $\mathrm{CI}=1.21-8.04, p=0.0135$ ) (Table IV). Moreover, multivariate analysis for conversion to surgery after chemotherapy revealed that low expression of MRE11 and RAD50 was an independent predictor for surgical resection after downstaging (MRE11: $\mathrm{OR}=21.17, \mathrm{CI}=5.83-94.83, p<0.0001$; RAD50: $\mathrm{OR}=17.98, \mathrm{CI}=4.78-84.25, p<0.0001)$ (Table V).

\section{Discussion}

In our current study, we found that the nuclear accumulation of MRN complex in GC tissues was associated with cancer progression, low nuclear expression of the DNA damage marker $\gamma \mathrm{H} 2 \mathrm{AX}$, and poor prognosis. In particular, high NBS1 expression in GC was an independent prognostic factor. Moreover, high MRN complex expression in biopsy samples from patients with unresectable GC was associated with poor prognosis, chemotherapeutic response, and surgical resection after down-staging by chemotherapy.

The clinical significance of MRE11, RAD50, and NBS1 expression as clinical markers has already been reported. Among them, high MRE11 is associated with poor prognosis and chemoresistance in colon cancer and breast cancer(24, 25). Moreover, high tumor NBS1 expression is a poor prognostic factor in breast cancer, prostate cancer, acute myeloid leukemia, and oral squamous cell carcinoma (2528). On the other hand, MRN complex expression is also associated with lower local recurrence rate after surgery in breast and esophageal cancer (29, 30). Moreover, Teo et al. reported that the sensitivity to radical radiotherapy is associated with MRE11 variant status in bladder cancer(31). Radiation therapy is rarely used as adjuvant therapy in current GC practice; therefore, we feel that our data for the association between MRN complex expression and poor prognostic factors is consistent with previous studies without adjuvant radiation treatments. This report is the first validation of relationships between MRN complex expression and chemosensitivity not only in surgical GC specimens, but also in biopsy samples from chemotherapynaïve patients presenting with unresectable GC at initial diagnosis.

In this study, MRN complex expression was associated with several clinicopathological factors in patients with GC. From previous reports, MRN complex functions in DNA DSBs repair, as well as in the regulation of proliferation and telomere stability $(11,25,32,33)$. Moreover, NBS1 overexpression in head and neck cancer was reported to function as an inducer of epithelial-mesenchymal transition, which enhances the ability of cells to undergo migration and invasion, and acquire cancer stem cell-like properties (34). Therefore, it was suggested that MRN complex expression would be associated with cancer progression and poor prognosis due to its ability to promote DNA DSB repair and increase the malignant potential of GC cells.

DNA repair machinery plays an important role in chemorefractive cancer; therefore, many researchers have focused on these proteins as therapeutic targets. Among them, we examined the MRN complex. MRN complex inhibition is reported to induce antitumor effect in several cancer types $(16,35,36)$. Moreover, MRN complex expression is known to be associated with resistance to hyperthermia and radiation 
A
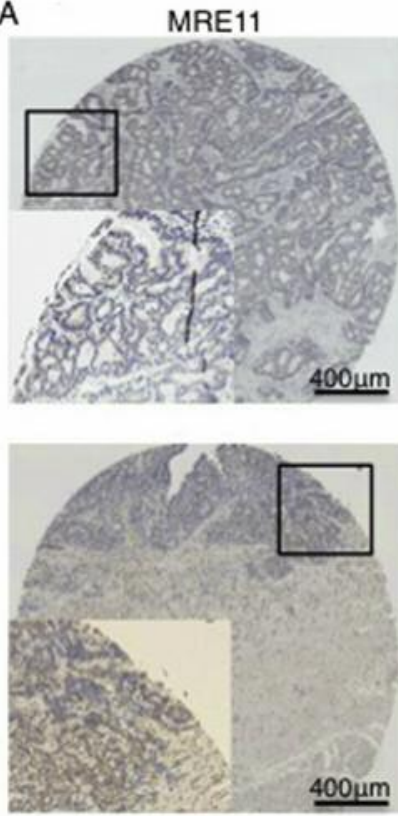

B
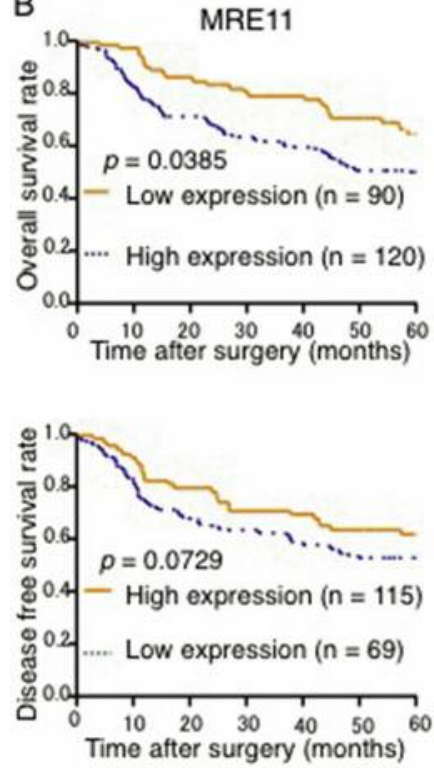

RAD50
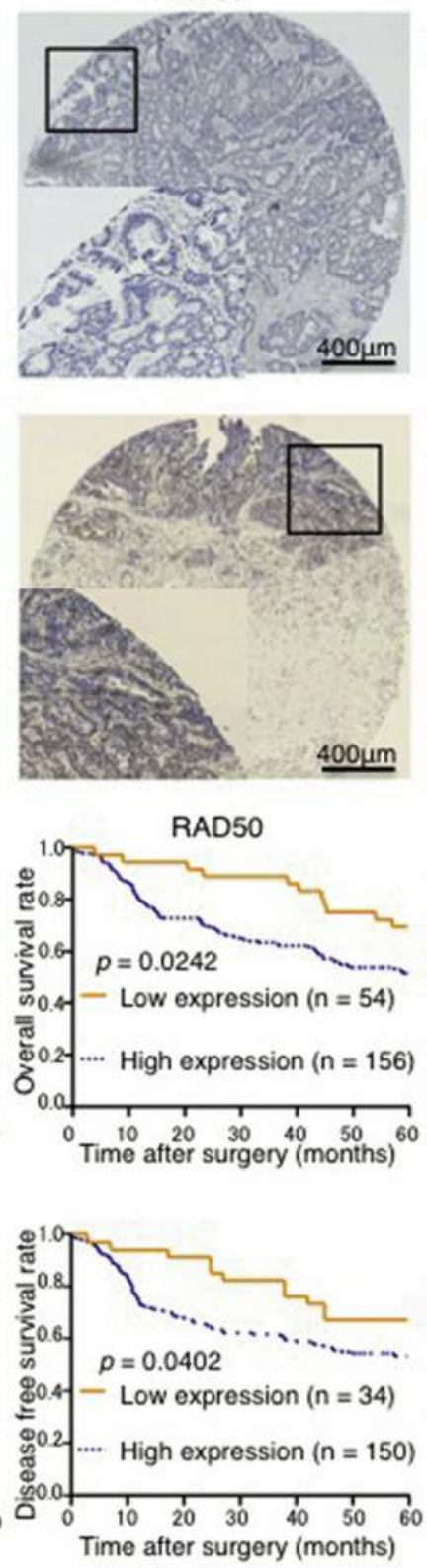

NBS1
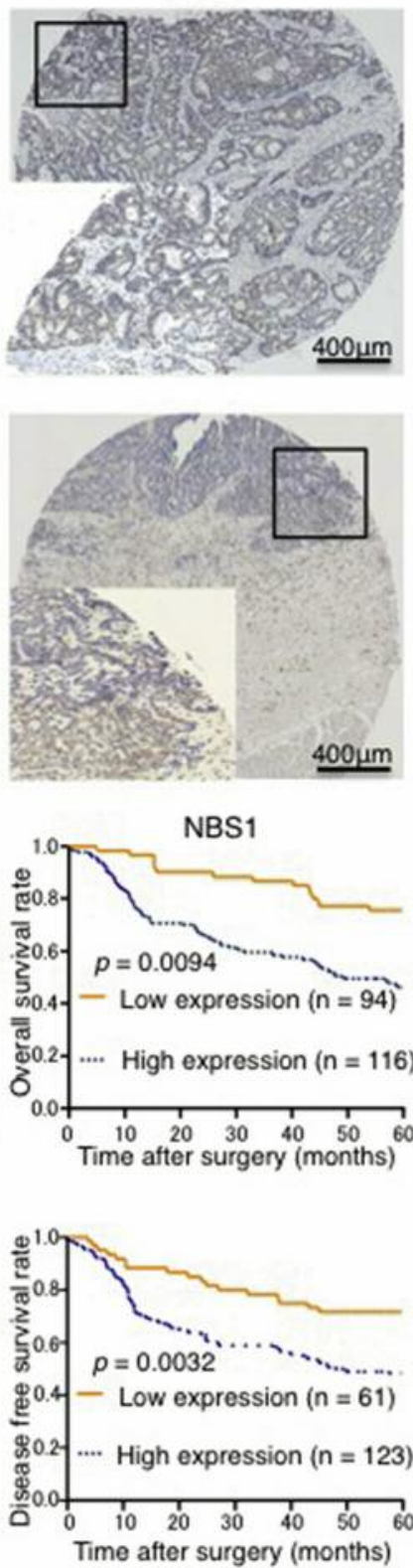

YH2AX
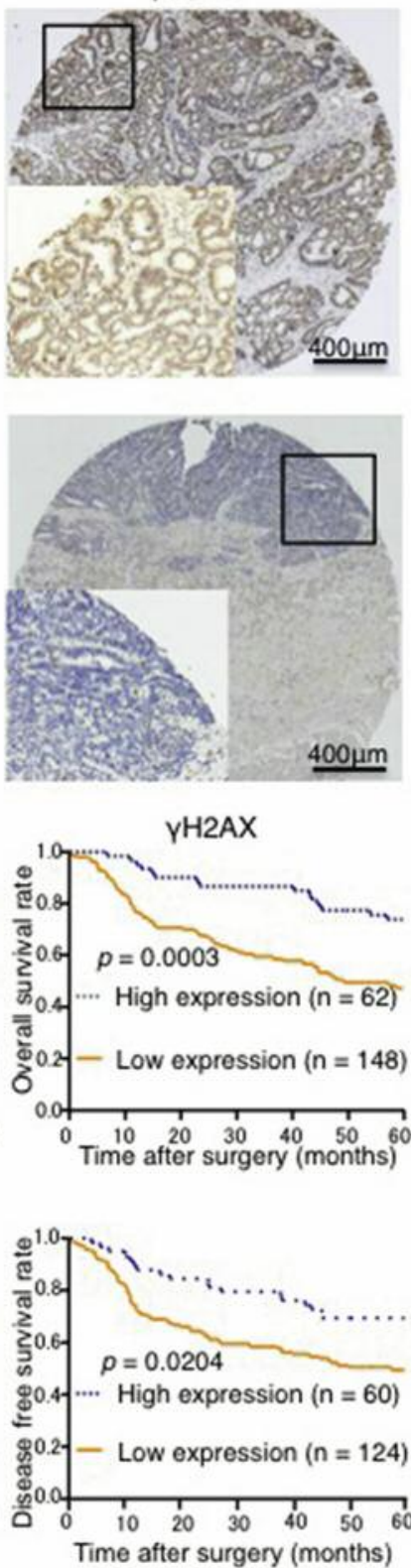

Figure 1. Immunohistochemical staining of meiotic recombination 11, DNA-repair protein Rad50 and Nijmegen breakage syndrome 1 (MRE11RAD50-NBS1 (MRN) complex and phosphorylated H2A histone family, member X ( $\gamma H 2 A X)$ in primary gastric cancer (GC). A: Representative images of GC with a low nuclear level of MRE11, RAD50 and NBS1, and nuclear accumulation of DNA damage marker $\gamma H 2 A X$ (upper panel). and GC with a high nuclear level of MRE11, RAD50 and NBS1, and decreased expression of $\gamma H 2 A X$ (lower panel). B: Overall survival curve of 210 patients with GC (upper panel) and disease-free survival curve of 184 patients with GC (lower panel) according to expression of MRE11, RAD50, NBS1 and $\gamma H 2 A X$.

therapy by reducing DNA damage by these therapeutic modalities $(37,38)$. In this study, we found that GC samples with high MRN complex expression exhibited a low nuclear expression of the DNA damage marker $\gamma \mathrm{H} 2 \mathrm{AX}$. Thus, the MRN complex might function to reduce DNA damage in patients with GC. Altogether, targeting the MRN complex is expected to be a promising therapeutic tool to overcome GC resistance to multimodal therapies.

In this study, we used biopsy samples to evaluate the expression of MRN complex and the chemotherapeutic 

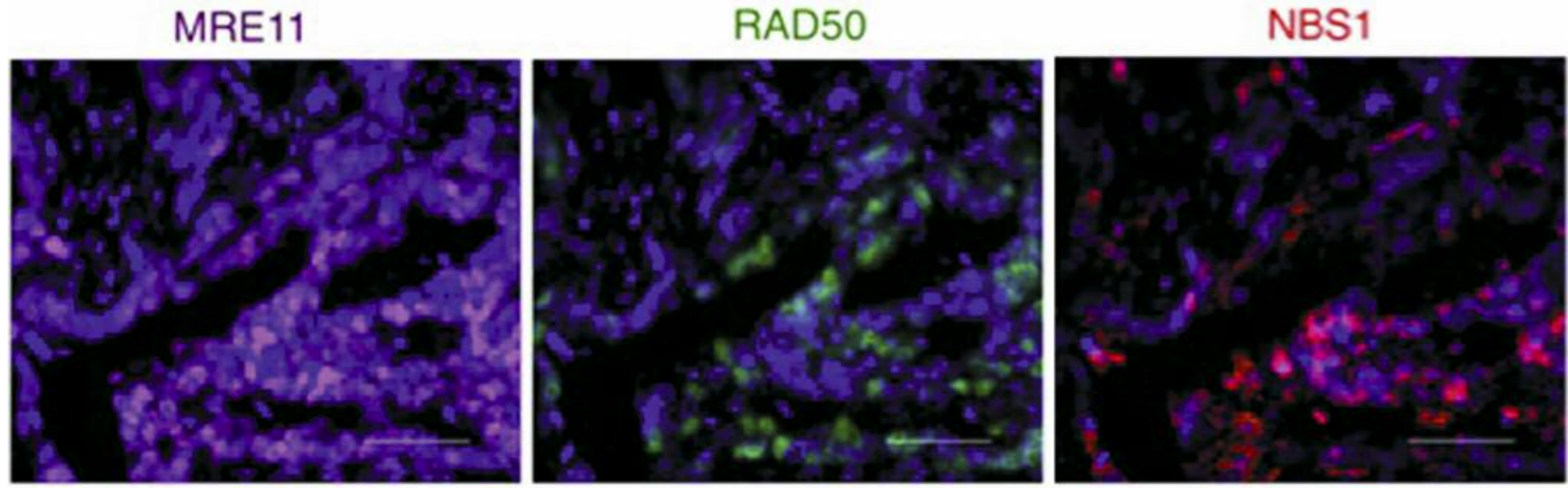

DAPI: nucleus

Figure 2. Fluorescence immunohistochemical analysis of meiotic recombination 11 (MRE11), DNA repair protein Rad50 (RAD50) and Nijmegen breakage syndrome 1 (NBS1) expression in gastric cancer (GC) tissues. Representative GC tissue was immunostained with the antibodies against MRE11 (purple), RAD50 (green), and NBS1 (red). All sections were counterstained with 4',6-diamidino-2-phenylindole (DAPI) (blue). Scale bar= $50 \mu m$.

A

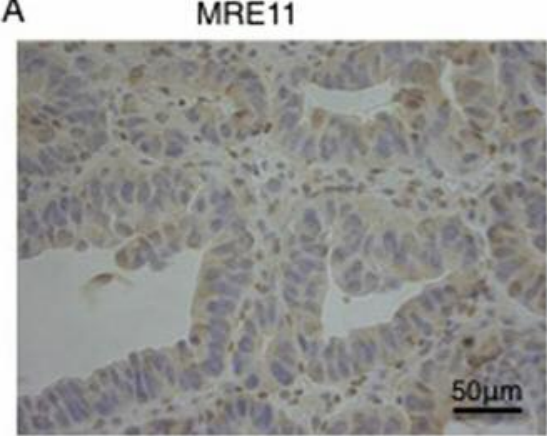

B

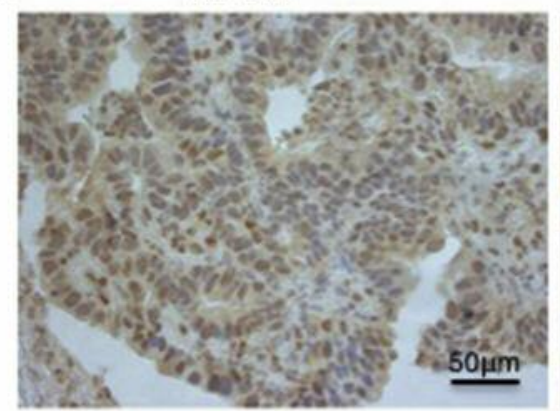

RAD50

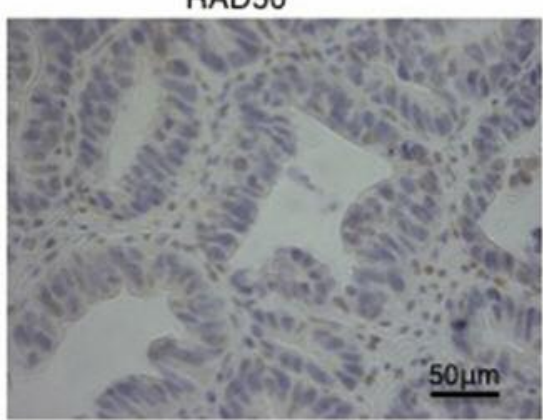

RAD50

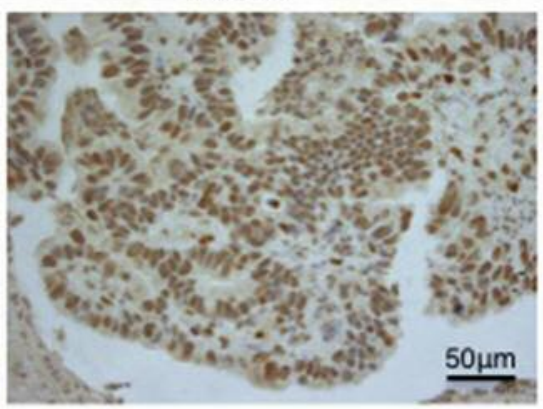

NBS1

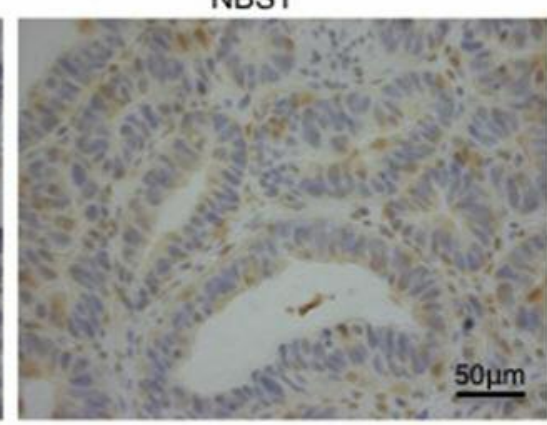

NBS1

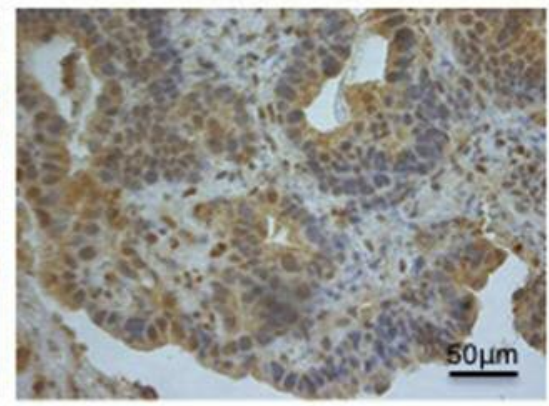

Figure 3. A: Representative images of biopsy samples from a patient with unresectable gastric cancer (GC) with low-level nuclear expression of meiotic recombination 11 (MRE11) in tumor demonstrating decreased nuclear expression of DNA repair protein Rad50 (RAD50) and Nijmegen breakage syndrome 1 (NBS1). B: Representative images of the biopsy sample from a patient with unresectable GC with high nuclear MRE11 expression in tumor and enhanced nuclear expression of RAD50 and NBS1.

response in patients with unresectable GC. Thus, this may bias the results of our study. However, our biopsy samples were adequate for evaluating the immunohistochemical staining of the MRN complex because of the non-heterogeneous expression of MRN complex in our surgical samples.
In conclusion, the nuclear accumulation of the MRN complex in surgical and biopsy samples from patients with GC was associated with cancer progression, reduced DNA damage, poor prognosis, and chemoresistance. These data suggest that the MRN complex might be a promising marker 
Table III. Association of meiotic recombination 11 (MRE11), DNA repair protein Rad50 (RAD50) and Nijmegen breakage syndrome 1 (NBS1) complex expression in 78 gastric cancer biopsy samples with clinicopathological factors.

\begin{tabular}{|c|c|c|c|c|c|c|c|c|c|}
\hline \multirow[t]{2}{*}{ Clinicopathologic variable } & \multicolumn{3}{|c|}{ MRE11 expression } & \multicolumn{3}{|c|}{ RAD50 expression } & \multicolumn{3}{|c|}{ NBS1 expression } \\
\hline & Low $(n=22)$ & High $(n=56)$ & $p$-Value & Low $(\mathrm{n}=19)$ & High $(\mathrm{n}=59)$ & $p$-Value & Low $(\mathrm{n}=12)$ & High $(n=66)$ & $p$-Value \\
\hline Age $($ mean \pm SD $)$, years & $60.3 \pm 9.1$ & $63.7 \pm 10.4$ & 0.1881 & $61.2 \pm 9.7$ & $63.2 \pm 10.2$ & 0.4418 & $55.8 \pm 9.3$ & $64 \pm 9.7$ & $0.0078 *$ \\
\hline \multicolumn{10}{|l|}{ Gender, n (\%) } \\
\hline Male & $13(59.1)$ & $40(71.4)$ & \multirow[t]{2}{*}{0.2934} & $10(52.6)$ & $43(72.9)$ & \multirow[t]{2}{*}{0.1} & $6(50.0)$ & $47(71.2)$ & \multirow[t]{2}{*}{0.1475} \\
\hline Female & $9(40.9)$ & $16(28.6)$ & & $9(47.4)$ & $16(27.1)$ & & $6(50.0)$ & $19(28.8)$ & \\
\hline \multicolumn{10}{|l|}{ Histology, n (\%) } \\
\hline Well, moderate & $10(45.5)$ & $22(39.3)$ & \multirow[t]{2}{*}{0.6182} & $11(57.9)$ & $21(35.6)$ & \multirow[t]{2}{*}{0.0856} & $4(33.3)$ & $28(42.4)$ & \multirow[t]{2}{*}{0.5559} \\
\hline Poor, signet & $12(54.5)$ & $34(60.7)$ & & $8(42.1)$ & $38(64.4)$ & & $8(66.7)$ & $38(57.6)$ & \\
\hline \multicolumn{10}{|l|}{ Tumor depth, n (\%) } \\
\hline SS & $5(22.7)$ & $7(12.5)$ & \multirow[t]{3}{*}{0.5291} & $6(31.6)$ & $6(10.2)$ & \multirow[t]{3}{*}{0.0768} & $2(16.7)$ & $10(15.2)$ & \multirow[t]{3}{*}{0.5739} \\
\hline SE & $14(63.7)$ & $40(71.4)$ & & $11(57.9)$ & $43(72.9)$ & & $7(58.3)$ & $47(71.2)$ & \\
\hline SI & $3(13.6)$ & $9(16.1)$ & & $2(10.5)$ & $10(16.9)$ & & $3(25.0)$ & $9(13.6)$ & \\
\hline \multicolumn{10}{|c|}{ Lymph node metastasis, n (\%) } \\
\hline Absent & $1(4.6)$ & $5(8.9)$ & \multirow[t]{2}{*}{0.5133} & $2(10.5)$ & $4(6.8)$ & \multirow[t]{2}{*}{0.594} & $1(8.3)$ & $5(7.6)$ & \multirow[t]{2}{*}{0.9278} \\
\hline Present & $21(95.4)$ & $51(91.1)$ & & $17(89.5)$ & $55(93.2)$ & & $11(91.7)$ & $61(92.4)$ & \\
\hline \multicolumn{10}{|l|}{ Hepatic metastases, $\mathrm{n}(\%)$} \\
\hline Absent & $20(90.9)$ & $47(83.9)$ & \multirow[t]{2}{*}{0.4254} & $17(89.5)$ & $50(84.8)$ & \multirow[t]{2}{*}{0.6066} & $11(91.7)$ & $56(84.9)$ & \multirow[t]{2}{*}{0.5325} \\
\hline Present & $2(9.1)$ & $9(16.1)$ & & $2(10.5)$ & $9(15.2)$ & & $1(8.3)$ & $10(15.1)$ & \\
\hline \multicolumn{10}{|l|}{ Distant metastases, n (\%) } \\
\hline Absent & $17(77.3)$ & $45(80.4)$ & \multirow[t]{2}{*}{0.7614} & $15(79.0)$ & $47(79.7)$ & \multirow{2}{*}{0.9466} & $11(91.7)$ & $51(77.3)$ & 0.256 \\
\hline Present & $5(22.7)$ & $11(19.6)$ & & $4(21.1)$ & $12(20.3)$ & & $1(8.3)$ & $15(22.7)$ & \\
\hline Peritoneal metastases, $\mathrm{n}(\%$ & & & & & & & & & \\
\hline Absent & $14(63.6)$ & $32(57.1)$ & 0.5998 & $12(63.2)$ & $34(57.6)$ & 0.6699 & $8(66.7)$ & $38(57.6)$ & 0.5559 \\
\hline Present & $8(36.4)$ & $24(42.9)$ & & $7(36.8)$ & $25(42.4)$ & & $4(33.3)$ & $28(42.4)$ & \\
\hline Clinical response, n (\%) & & & & & & & & & \\
\hline Partial response & $18(81.8)$ & $28(50.9)$ & $0.0436^{*}$ & $15(79.0)$ & $31(53.5)$ & 0.0803 & $9(75.0)$ & $37(56.9)$ & 0.4089 \\
\hline Stable disease & $2(9.1)$ & $15(27.3)$ & & $3(15.8)$ & $14(24.1)$ & & $1(8.3)$ & $16(24.6)$ & \\
\hline Progressive disease & $2(9.1)$ & $12(21.8)$ & & $1(5.2)$ & $13(22.4)$ & & $2(16.7)$ & $12(18.5)$ & \\
\hline Chemotherapy, n (\%) & & & & & & & & & \\
\hline Cisplatin & $10(45.5)$ & $21(37.5)$ & 0.5183 & $10(52.6)$ & $21(35.6)$ & 0.1869 & $6(50.0)$ & $25(37.9)$ & 0.43 \\
\hline Paclitaxel & $12(54.5)$ & $35(62.5)$ & & $9(47.4)$ & $38(64.4)$ & & $6(50.0)$ & $41(62.1)$ & \\
\hline Surgical status after CTx & & & & & & & & & \\
\hline No surgery & $7(31.8)$ & $50(89.3)$ & $<0.0001 *$ & $6(31.6)$ & $51(86.4)$ & $<0.0001 *$ & $6(50.0)$ & $51(77.3)$ & 0.0501 \\
\hline Surgery & $15(68.2)$ & $6(10.7)$ & & $13(68.4)$ & $8(13.6)$ & & $6(50.0)$ & $15(22.7)$ & \\
\hline
\end{tabular}

SM: Submucosal invasion; MP: muscularis propria invasion; SS: subserosal invasion; SE: serosal invasion; SI: surrounding organ invasion, CTx: chemotherapy. *Significant difference.

for poor prognosis and chemoresistance in GC. Moreover, MRN complex inhibition may be an effective therapeutic approach to overcome chemoresistance in GC by blocking the DNA DSB repair; however, further studies are required to evaluate the full role of the MRN complex and its clinical application for GC treatment.

\section{Conflicts of Interest and Funding}

Masahiko Nishiyama received a research grant from Yakult Honsha Co. Ltd. Grants-in-Aid for Scientific Research from the Japan Society for the Promotion of Science (JSPS); grant numbers 22591450, 22591449,23591857 , and 15K10085. The work was supported in part by Promotion plan for the platform of Human Resource Development for cancer and New Paradigms Establishing Centers for Fostering medical researchers of the Future programs by ministry of Education, Culture, Sports, Science and Technology of Japan, and Gunma University Initiative for Advanced Research (GIAR).

\section{Acknowledgements}

The Authors would like to thank Ms. Yukie Saito, Ms. Tomoko Yano, Ms. Yuka Matsui, and Ms. Ayaka Ishida, and Ms. Ayaka Ishikubo for their excellent assistance.

\section{Rererences}

1 Ferlay J, Soerjomataram I, Dikshit R, Eser S, Mathers C, Rebelo M, Parkin DM, Forman D and Bray F: Cancer incidence and mortality worldwide: Sources, methods and major patterns in Globocan 2012. Int J Cancer 136(5): E359-386, 2015. 
A

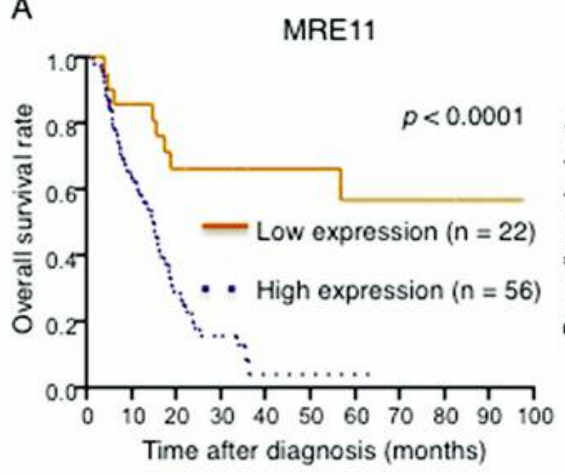

B

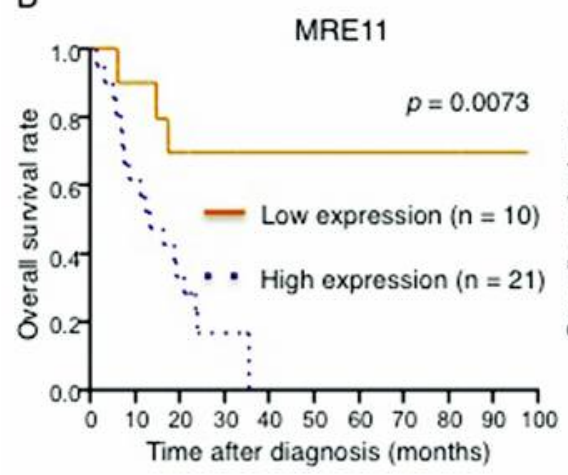

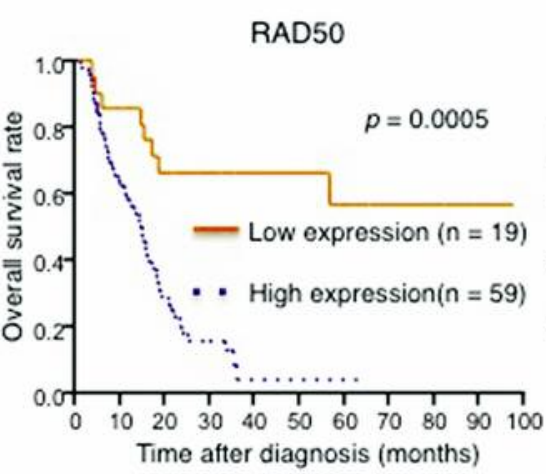

RAD50

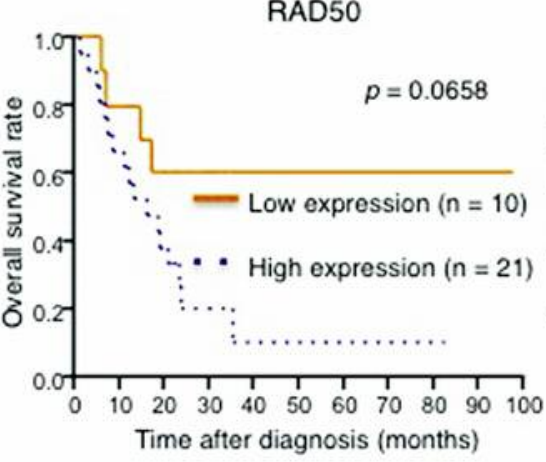

NBS1

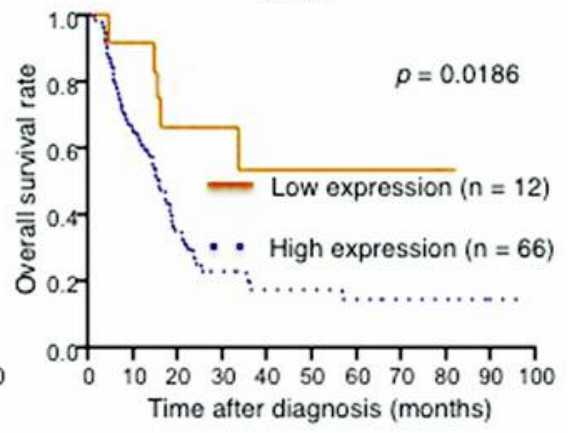

NBS1

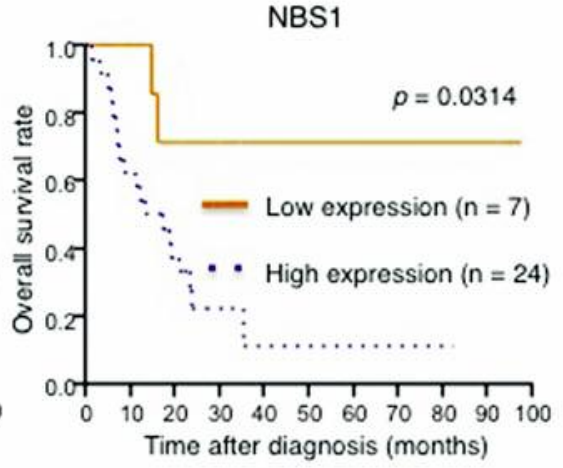

C
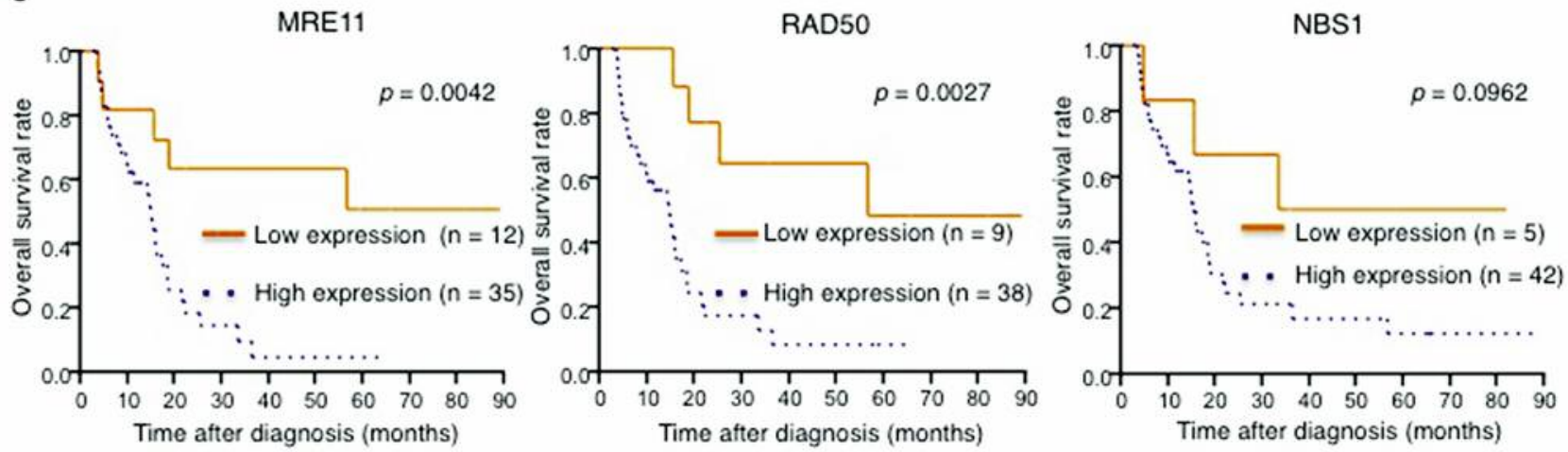

Figure 4. Correlation of overall survival with the expression of nuclear meiotic recombination 11 (MRE11), DNA repair protein Rad50 (RAD50) and Nijmegen breakage syndrome 1 (NBS1) complex in 78 biopsy samples before chemotherapy from patients with unresectable gastric cancer $(G C)$ at initial diagnosis. A: Overall survival rate according to nuclear expression of MRE11, RAD50, and NBS1. B: Overall survival rate of 31 patients with unresectable GC at initial diagnosis treated by cisplatin plus TS-1 as first-line regimen according to nuclear expression of MRE11, RAD50, and NBS1. C: Overall survival rate of 47 patients with unresectable GC at initial diagnosis treated by paclitaxel plus TS-1 as first-line regimen according to nuclear expression of MRE11, RAD50, and NBS1.

2 Cidon EU, Ellis SG, Inam Y, Adeleke S, Zarif S and Geldart T: Molecular targeted agents for gastric cancer: A step forward towards personalized therapy. Cancers 5(1): 64-91, 2013.

3 Pitroda SP, Pashtan IM, Logan HL, Budke B, Darga TE, Weichselbaum RR and Connell PP: DNA-repair pathway geneexpression score correlates with repair proficiency and tumor sensitivity to chemotherapy. Sci Transl Med 6(229): 229ra242, 2014.
4 Kavitha CV, Choudhary B, Raghavan SC and Muniyappa K: Differential regulation of MRN (MRE11-RAD50-NBS1) complex subunits and telomerase activity in cancer cells. Biochem Biophys Res Commun 399(4): 575-580, 2010.

5 Heikkinen K, Rapakko K, Karppinen SM, Erkko H, Knuutila S, Lundan T, Mannermaa A, Borresen-Dale AL, Borg A, Barkardottir RB, Petrini J and Winqvist R: RAD50 and NBS1 are breast cancer susceptibility genes associated with genomic instability. Carcinogenesis 27(8): 1593-1599, 2006. 
Table IV. Univariate and multivariate analyses of clinicopathological factors according to the Japanese Classification of Gastric Carcinoma affecting overall survival of patients with unresectable gastric cancer. Protein expression was determined from biopsy specimens.

\begin{tabular}{|c|c|c|c|c|c|c|c|c|c|c|c|c|}
\hline \multirow[t]{2}{*}{ Clinicopathological variable } & \multicolumn{3}{|c|}{ Univariate } & \multicolumn{3}{|c|}{ Multivariate (MRE11) } & \multicolumn{3}{|c|}{ Multivariate (RAD50) } & \multicolumn{3}{|c|}{ Multivariate (NBS1) } \\
\hline & $\mathrm{RR}$ & $95 \% \mathrm{CI}$ & $p$-Value & $\mathrm{RR}$ & $95 \% \mathrm{CI}$ & $p$-Value & $\mathrm{RR}$ & $95 \% \mathrm{CI}$ & $p$-Value & $\mathrm{RR}$ & $95 \% \mathrm{CI}$ & $p$-Value \\
\hline Age: $<65 / \geq 65$ years & 1.06 & $0.62-1.8$ & 0.844 & - & - & - & - & - & - & - & - & - \\
\hline Gender: Male/female & 1.23 & $0.69-2.27$ & 0.4811 & - & - & - & - & - & - & - & - & - \\
\hline \multicolumn{13}{|l|}{ Histology grade: } \\
\hline Differentiated/undifferentiated & 1.66 & $0.95-3.00$ & 0.0718 & - & - & - & - & - & - & - & - & - \\
\hline Tumor depth: SS, SE/SI & 0.72 & $0.31-1.45$ & 0.3786 & - & - & - & - & - & - & - & - & - \\
\hline Lymph node metastasis: Absent/present & 0.52 & $0.24-1.37$ & 0.1719 & - & - & - & - & - & - & - & - & - \\
\hline Hepatic metastases: Absent/present & 1.5 & $0.68-2.95$ & 0.293 & - & - & - & - & - & - & - & - & - \\
\hline Distant metastases: Absent/present & 1.67 & $0.83-3.10$ & 0.1418 & - & - & - & - & - & - & - & - & - \\
\hline Peritoneal metastases: Absent/present & 1.58 & $0.91-2.70$ & 0.1028 & - & - & - & - & - & - & - & - & - \\
\hline Stage: III/IV & 2.62 & $1.14-7.59$ & $0.0206^{*}$ & 2.4 & $1.04-6.96$ & $0.0384 *$ & 2.81 & $1.84-8.64$ & $0.0127 *$ & 2.52 & $1.09-7.32$ & 0.290 \\
\hline MRE11 expression: Low/high & 4.37 & $2.12-10.28$ & $<0.0001 *$ & 4.18 & $2.03-9.80$ & $<0.0001 *$ & - & - & - & - & - & - \\
\hline RAD50 expression: Low/high & 3.59 & $1.77-8.28$ & $0.0002 *$ & - & - & - & 3.73 & $1.22-8.17$ & $<0.0001 *$ & * - & - & - \\
\hline NBS1 expression: Low/high & 2.88 & $1.28-8.34$ & $0.0097 *$ & - & - & - & - & - & - & 2.78 & $1.21-8.04$ & $0.0135^{*}$ \\
\hline
\end{tabular}

MRE11: Meiotic recombination 11; RAD50: DNA-repair protein Rad50; NBS1: Nijmegen breakage syndrome 1; SS: subserosal invasion; SE: serosal invasion; SI: surrounding organ invasion; RR: relative risk; CI: confidence interval. *Significant result.

Table V. Multivariate analyses of existing factors affecting resectability and meiotic recombination 11 (MRE11), DNA-repair protein Rad50 (RAD50) and Nijmegen breakage syndrome 1 (NBS1) affecting surgery after down-staging by chemotherapy for unresectable gastric cancer.

\begin{tabular}{|c|c|c|c|c|c|c|c|c|c|}
\hline \multirow[t]{2}{*}{ Clinicopathological variable } & \multicolumn{3}{|c|}{ MRE11 } & \multicolumn{3}{|c|}{ RAD50 } & \multicolumn{3}{|c|}{ NBS1 } \\
\hline & OR & $95 \% \mathrm{CI}$ & $p$-Value & OR & $95 \% \mathrm{CI}$ & $p$-Value & OR & $95 \% \mathrm{CI}$ & $p$-Value \\
\hline Tumor depth: SS,SE/SI & 1.53 & $0.29-9.74$ & 0.6197 & 1.36 & $0.27-8.43$ & 0.7168 & 2.13 & $0.50-11.58$ & 0.3137 \\
\hline Hepatic metastases: Absent/present & $7.03 \mathrm{E}+07$ & $3.67-\ddagger$ & $0.003 *$ & $8.00 \mathrm{E}+08$ & $4.16-\ddagger$ & $0.0019 *$ & $1.97 \mathrm{E}+07$ & $5.644 \mathrm{E}+22-\ddagger$ & $0.0025^{*}$ \\
\hline Peritoneal metastases: Absent/present & 2.53 & $0.66-11.07$ & 0.1756 & 2.66 & $0.72-11.34$ & 0.1434 & 2.31 & $0.77-7.44$ & 0.1386 \\
\hline MRE11expression: Low/high & 21.17 & $5.83-94.83$ & $<0.0001 *$ & - & - & - & - & - & - \\
\hline RAD50 expression: Low/high & - & - & - & 17.98 & $4.78-84.25$ & $<0.0001^{*}$ & - & - & - \\
\hline NBS1 expression: Low/high & - & - & - & - & - & - & 3.41 & $0.86-14.43$ & 0.0806 \\
\hline
\end{tabular}

OR, Odds ratio of avoiding surgery to having to undergo surgery; CI, confidence interval; SS: subserosal invasion; SE: serosal invasion; SI: surrounding organ invasion. *Significant result.

6 Sun H, Wang Y, Wang Z, Meng J, Qi Z and Yang G: Aurora-a controls cancer cell radio- and chemoresistance via ATM/CHK2mediated DNA repair networks. Biochim Biophys Acta 1843(5): 934-944, 2014.

$7 \mathrm{Li} \mathrm{W}$ and Melton DW: Cisplatin regulates the MAPK kinase pathway to induce increased expression of DNA repair gene ercc1 and increase melanoma chemoresistance. Oncogene 31(19): 2412-2422, 2012.

8 He J, Shi LZ, Truong LN, Lu CS, Razavian N, Li Y, Negrete A, Shiloach J, Berns MW and Wu X: RAD50 zinc hook is important for the mre11 complex to bind chromosomal DNA double-stranded breaks and initiate various DNA damage responses. J Biol Chem 287(38): 31747-31756, 2012.

9 Czornak K, Chughtai S and Chrzanowska KH: Mystery of DNA repair: The role of the MRN complex and ATM kinase in DNA damage repair. J Appl Genet 49(4): 383-396, 2008.

10 Stracker TH, Carson CT and Weitzman MD: Adenovirus oncoproteins inactivate the MRE11-RAD50-NBS1 DNA repair complex. Nature 418(6895): 348-352, 2002.
11 Deng Y, Guo X, Ferguson DO and Chang S: Multiple roles for MRE11 at uncapped telomeres. Nature 460(7257): 914-918, 2009.

12 Khongkow P, Karunarathna U, Khongkow M, Gong C, Gomes AR, Yague E, Monteiro LJ, Kongsema M, Zona S, Man EP, Tsang JW, Coombes RC, Wu KJ, Khoo US, Medema RH, Freire $\mathrm{R}$ and Lam EW: FOXM1 targets NBS1 to regulate DNA damage-induced senescence and epirubicin resistance. Oncogene 33(32): 4144-4155, 2014.

13 Guo Z, Kozlov S, Lavin MF, Person MD and Paull TT: ATM activation by oxidative stress. Science 330(6003): 517-521, 2010.

14 Zhao H, Traganos F, Albino AP and Darzynkiewicz Z: Oxidative stress induces cell cycle-dependent MRE11 recruitment, ATM and CHK2 activation and histone h2ax phosphorylation. Cell Cycle 7(10): 1490-1495, 2008.

15 Lee JH and Paull TT: ATM activation by DNA double-strand breaks through the MRE11-RAD50-NBS1 complex. Science 308(5721): 551-554, 2005. 
16 Abuzeid WM, Jiang X, Shi G, Wang H, Paulson D, Araki K, Jungreis D, Carney J, O'Malley BW Jr. and Li D: Molecular disruption of RAD50 sensitizes human tumor cells to cisplatinbased chemotherapy. J Clin Invest 119(7): 1974-1985, 2009.

17 Leon-Galicia I, Diaz-Chavez J, Garcia-Villa E, Uribe-Figueroa L, Hidalgo-Miranda A, Herrera LA, Alvarez-Rios E, GarciaMena $\mathrm{J}$ and Gariglio P: Resveratrol induces downregulation of DNA repair genes in MCF-7 human breast cancer cells. Eur J Cancer Prev 22(1): 11-20, 2013.

18 Olson E, Nievera CJ, Lee AY, Chen L and Wu X: The MRE11RAD50-NBS1 complex acts both upstream and downstream of ataxia telangiectasia mutated and RAD3-related protein (ATR) to regulate the S-phase checkpoint following UV treatment. J Biol Chem 282(31): 22939-22952, 2007.

19 Xia C, Ye F, Hu X, Li Z, Jiang B, Fu Y, Cheng X, Shao Z and Zhuang Z: Liver kinase B1 enhances chemoresistance to gemcitabine in breast cancer MDA-MB-231 cells. Oncol Lett 8(5): 2086-2092, 2014

20 Matsutani N, Yokozaki H, Tahara E, Tahara H, Kuniyasu H, Kitadai Y, Haruma K, Chayama K, Tahara E and Yasui W: Expression of MRE11 complex (MRE11, RAD50, NBS1) and HRAP1 and its relation with telomere regulation, telomerase activity in human gastric carcinomas. Pathobiology 69(4): 219224, 2001

21 Mochiki E, Ogata K, Ohno T, Toyomasu Y, Haga N, Fukai Y, Aihara R, Ando H, Uchida N, Asao T, Kuwano H and North Kanto Gastric Cancer Study G: Phase II multi-institutional prospective randomised trial comparing $\mathrm{S}$-1+paclitaxel with $\mathrm{S}$ $1+$ cisplatin in patients with unresectable and/or recurrent advanced gastric cancer. Br J Cancer 107(1): 31-36, 2012.

22 Japanese Gastric Cancer A: Japanese classification of gastric carcinoma - 2nd English edition. Gastric Cancer 1(1): 10-24, 1998.

23 Altan B, Yokobori T, Mochiki E, Ohno T, Ogata K, Ogawa A, Yanai M, Kobayashi T, Luvsandagva B, Asao T and Kuwano H: Nuclear karyopherin-alpha2 expression in primary lesions and metastatic lymph nodes was associated with poor prognosis and progression in gastric cancer. Carcinogenesis 34(10): 2314 2321, 2013.

24 Pavelitz T, Renfro L, Foster NR, Caracol A, Welsch P, Lao VV, Grady WB, Niedzwiecki D, Saltz LB, Bertagnolli MM, Goldberg RM, Rabinovitch PS, Emond M, Monnat RJ, Jr. and Maizels N: MRE11-deficiency associated with improved longterm disease free survival and overall survival in a subset of stage III colon cancer patients in randomized CALGB 89803 trial. PLoS One 9(10): e108483, 2014.

25 Yuan SS, Hou MF, Hsieh YC, Huang CY, Lee YC, Chen YJ and Lo S: Role of MRE11 in cell proliferation, tumor invasion, and DNA repair in breast cancer. J Natl Cancer Inst 104(19): 1485$1502,2012$.

26 Grupp K, Boumesli R, Tsourlakis MC, Koop C, Wilczak W, Adam M, Sauter G, Simon R, Izbicki JR, Graefen M, Huland H, Steurer S, Schlomm T, Minner S and Quaas A: The prognostic impact of high Nijmegen breakage syndrome (NBS1) gene expression in erg-negative prostate cancers lacking PTEN deletion is driven by kpna2 expression. Int $\mathrm{J}$ Cancer 135(6): 1399-1407, 2014.
27 Kefala M, Papageorgiou SG, Kontos CK, Economopoulou P, Tsanas A, Pappa V, Panayiotides IG, Gorgoulis VG, Patsouris E and Foukas PG: Increased expression of phosphorylated nbs1, a key molecule of the DNA damage response machinery, is an adverse prognostic factor in patients with de novo myelodysplastic syndromes. Leuk Res 37(11): 1576-1582, 2013.

28 Hsu DS, Chang SY, Liu CJ, Tzeng CH, Wu KJ, Kao JY and Yang MH: Identification of increased nbs 1 expression as a prognostic marker of squamous cell carcinoma of the oral cavity. Cancer Sci 101(4): 1029-1037, 2010.

29 Soderlund K, Stal O, Skoog L, Rutqvist LE, Nordenskjold B and Askmalm MS: Intact MRE11/RAD50/NBS1 complex predicts good response to radiotherapy in early breast cancer. Int J Radiat Oncol Biol Phys 68(1): 50-58, 2007.

30 Kuo KT, Chou TY, Hsu HS, Chen WL and Wang LS: Prognostic significance of NBS1 and SNAIL expression in esophageal squamous cell carcinoma. Ann Surg Oncol 19(Suppl 3): S549$557,2012$.

31 Teo MT, Dyrskjot L, Nsengimana J, Buchwald C, Snowden H, Morgan J, Jensen JB, Knowles MA, Taylor G, Barrett JH, Borre M, Orntoft TF, Bishop DT and Kiltie AE: Next-generation sequencing identifies germline MRE11A variants as markers of radiotherapy outcomes in muscle-invasive bladder cancer. Ann Oncol 25(4): 877-883, 2014.

32 Chiang YC, Teng SC, Su YN, Hsieh FJ and Wu KJ: C-myc directly regulates the transcription of the $N B S 1$ gene involved in DNA double-strand break repair. J Biol Chem 278(21): 1928619291, 2003.

33 Zhang Y, Zhou $\mathrm{J}$ and Lim CU: The role of NBS1 in DNA double-strand break repair, telomere stability, and cell cycle checkpoint control. Cell Res 16(1): 45-54, 2006.

34 Yang MH, Chang SY, Chiou SH, Liu CJ, Chi CW, Chen PM, Teng SC and $\mathrm{Wu} \mathrm{KJ}$ : Overexpression of NBS1 induces epithelial-mesenchymal transition and co-expression of NBS1 and snail predicts metastasis of head and neck cancer. Oncogene 26(10): 1459-1467, 2007.

35 Gao R, Singh R, Kaul Z, Kaul SC and Wadhwa R: Targeting of DNA damage signaling pathway induced senescence and reduced migration of cancer cells. J Gerontol A Biol Sci Med Sci, 2014.

36 Ying S, Hamdy FC and Helleday T: MRE11-dependent degradation of stalled DNA replication forks is prevented by BRCA2 and PARP1. Cancer Res 72(11): 2814-2821, 2012.

37 Xu M, Myerson RJ, Hunt C, Kumar S, Moros EG, Straube WL and Roti Roti JL: Transfection of human tumour cells with MRE11 siRNA and the increase in radiation sensitivity and the reduction in heat-induced radiosensitization. Int J Hyperthermia 20(2): 157-162, 2004.

38 Seno JD and Dynlacht JR: Intracellular redistribution and modification of proteins of the MRE11/RAD50/NBS1 DNA repair complex following irradiation and heat-shock. J Cell Physiol 199(2): 157-170, 2004.
Received July 27, 2016

Revised September 2, 2016 Accepted September 21, 2016 